\title{
Irrigation water regime and manure extract for wheat production grown under drip irrigation
}

\author{
AbdElgalil M.A.S. ${ }^{1}$, Abdel-Gawad A.M.A. ${ }^{2 *}$ \\ ${ }^{1}$ Central Laboratory of Organic Agriculture, Agricultural Research Centre, 9 Gamaa Street, 12619 Giza, Egypt \\ ${ }^{2}$ Soils and Water Department, Faculty of Agriculture, Al-Azhar University, Assiut 71524, Egypt
}

\begin{abstract}
A field experiment was carried out at the Experimental Farm of Arab El- Awammer Research Station, Agriculture Research Center, Assiut, Egypt during two consecutive growing seasons of 2017/18 and 2018/19. The aim is to study the effect of two manure extract (chicken manure and sheep manure extract) and two wheat varieties (Giza-171 and Misr-1) irrigated with drip irrigation at 100, 80 and $60 \%$ of crop evapotranspiration $\left(\mathrm{ET}_{\mathrm{c}}\right)$ on their traits and yields and as well as water productivity. The seasonal irrigation water applied as average of both seasons was $2488.1,1990.5$ and $1492.9 \mathrm{~m}^{3} /$ feddan (feddan $=0.420$ hectares $=1.037$ acres $)$ for 100,80 and $60 \% \mathrm{ET}_{\mathrm{c}}$, respectively. Irrigated wheat crop at $100 \% \mathrm{ET}_{\mathrm{c}}$ significantly increased wheat yield and its components compared to 80 or $60 \% \mathrm{ET}_{\mathrm{c}}$. The addition of manure extract specially sheep manure extract boosted wheat yield and its traits. Crop water productivity was positively affected by either irrigation water or manure extract application. On the average basis, water productivity was $0.53,0.62$ and $0.69 \mathrm{~kg} / \mathrm{m}^{3}$ for control, chicken and sheep manure extract, respectively in the $1^{\text {st }}$ season. They were $0.63,0.74$ and $0.83 \mathrm{~kg} / \mathrm{m}^{3}$ for the corresponding treatments in the $2^{\text {nd }}$ season. It was observed that adding sheep manure extract to wheat plants irrigated at $100 \mathrm{ET}_{\mathrm{c}}$ was the best agriculture practice that produce higher wheat yield as well as high crop water productivity.
\end{abstract}

Keywords: wheat, chicken manure, sheep manure, drip irrigation, crop evapotranspiration. 


\section{Introduction}

Organic farming is a production system, which avoids or largely excludes the use of synthetic or inorganic fertilizers, pesticides and growth regulators that support organic agriculture and to a certain extent this is also true for integrated production systems (Reddy, 2005). Organic matter in soil improves its structure, nutrient retention, aeration, soil moisture holding capacity and water infiltration (Deksissa et al., 2008). Although organic amendments can provide available nutrients for plants and nutrient transformation during organic matter decomposition strongly interacts with plant nutrient uptake come up with nutrients competition between soil microorganisms and plants. Further, these systems are beneficial for the overall health of the agricultural ecosystem. Development and management of effective fertilization practices (manipulating the quantity and type of organic amendments) improve soil ecosystems and fertility (Manqiang et al., 2009). Organic fertilizers including farmyard, sheep and poultry manure may be used for crop production to partially replacement chemical fertilizers. Poultry manure may be used as an organic amendment to restore degraded soils (Sanchez-Monedero et al., 2004). Similarly, animal wastes and green manures are used to increase some nutrients and to build up soil organic matter content. Worldwide, interest in the use of manures is increasing day by day due to soil fertility degradation. Economic premiums for certified organic grains have been driving many transition decisions related to the organic farming. Continuous use of chemical fertilizers potential pollutes the environment. Synthesis of chemical fertilizers consumes a large amount of energy and money (Delate and Camberdella, 2004; Oad et al., 2004). Wheat is the most important cereal crop as staple food grain in Egypt. The local production of wheat is not enough to supply the annual demand of the increasing population. Hence, increasing wheat production is the most important possibility for reducing the wheat gap and reach self-sufficiency of wheat production by two ways; first expanding the cultivated area, second maximizing the yield per unit area. Most of the new reclaimed areas in Egypt are sand or sandy calcareous soils (23-30\% of the total area is calcareous soils) which is considering as a promising area for wheat production (Abou-Elela, 2002). Also, it was reported that irrigation water is relatively insufficient and limited for reclamation and irrigation purposes. Therefore, water shortage is a major limiting factor for crop production. However, the increasing costs of chemical fertilizers and the hazardous effect of soil salinity as well as agricultural environment pollution that affect human health are the main challenge problems. Therefore, it is highly recommended to utilize these areas for crop production by partially replacing inorganic fertilizers by organic ones (Gewaily, 2019; Refai et al., 2019). The current investigation was initiated to assess the effect of irrigation regimes, manure application and wheat varieties on the wheat traits and its yield as well as wheat water relationship. 


\section{Materials and methods}

A field experiment was carried out during winter seasons of 2017/2018 and 2018/2019 at Asyut Agriculture Research Station (latitude $27.03^{\circ}, 11 \mathrm{~N}$ and longitude 31. $01^{\circ}$ 'E), Asyut Governorate, Egypt. The experiment was conducted in sandy calcareous soil that contains $90 \%$ sand, $6.5 \%$ silt, $3.5 \%$ clay, $0.35 \%$ organic matter and $32.6 \% \mathrm{CaCO} 3$ with soil salinity of $0.80 \mathrm{EC}_{\mathrm{e}} \mathrm{dS} / \mathrm{m}$ and soil reaction $(\mathrm{pH})$ of 8.10 . It contains $0.01 \%$ total $\mathrm{N}$ and $8.3 \mathrm{ppm}$ available $\mathrm{P}$. The meteorological data of the experimental site during both growing seasons are presented in Table (1). The experiment was laid in split-split-plot randomized complete block design with three replications. The plot area was 12.5 $\mathrm{m}^{2}$ (2.5m width and $5 \mathrm{~m}$ length). The main plot was assigned to manure application which was chicken $(\mathrm{CH})$ and sheep ( $\mathrm{SH})$ extract. The sub-plot was allocated for irrigation regimes which were 100,80 and $60 \%$ of crop evapotranspiration (ETc). The wheat varieties of Giza-171 and Misr-1were assigned to sub-sub-plot. In addition to a plot received recommended chemical fertilizer that was set as control treatment (CK).

Table (1): The meteorological data of Arab El-Awammer Research Station, Assiut, Egypt during both growing seasons of 2017/18 and 2018/19.

\begin{tabular}{|c|c|c|c|c|c|c|}
\hline \multirow{2}{*}{ Month } & \multicolumn{2}{|c|}{ Temperature $\left({ }^{\circ} \mathrm{C}\right)$} & \multirow{2}{*}{\begin{tabular}{|c|} 
Relative \\
humidity $(\%)$
\end{tabular}} & \multirow{2}{*}{$\begin{array}{c}\text { Wind speed } \\
\text { (km/day) }\end{array}$} & \multirow{2}{*}{$\begin{array}{c}\begin{array}{c}\text { Sunshine } \\
\text { (hours) }\end{array}\end{array}$} & \multirow{2}{*}{$\begin{array}{c}\text { ETo } \\
\text { (mm/day) }\end{array}$} \\
\hline & Max & Min & & & & \\
\hline \multicolumn{7}{|l|}{$2017 / 18$} \\
\hline December & 23.2 & 9.0 & 58.8 & 14.6 & 9.0 & 3.98 \\
\hline January & 19.9 & 6.5 & 57.4 & 15.3 & 8.9 & 3.77 \\
\hline February & 26.1 & 11.2 & 44.3 & 14.4 & 9.7 & 5.63 \\
\hline March & 30.5 & 14.2 & 36.2 & 16.9 & 9.9 & 7.90 \\
\hline April & 32.4 & 16.6 & 36.2 & 18.4 & 10.3 & 9.15 \\
\hline \multicolumn{7}{|l|}{$2018 / 19$} \\
\hline December & 20.8 & 8.0 & 62.8 & 16.3 & 9.0 & 3.62 \\
\hline January & 19.3 & 5.8 & 52.8 & 13.9 & 8.9 & 3.70 \\
\hline February & 21.8 & 7.6 & 51.4 & 17.3 & 9.7 & 4.93 \\
\hline March & 24.7 & 9.9 & 42.9 & 19.8 & 9.9 & 6.64 \\
\hline April & 29.6 & 14.0 & 36.5 & 21.3 & 10.3 & 8.93 \\
\hline
\end{tabular}

ETo $=$ Reference evapotranspiration.

The organic extracts of chicken or sheep manure were prepared by soaking 1: 10 manure: water $\mathrm{w} / \mathrm{w}$ for three days and the filtered solution was injected in the drip irrigation system twice. The first injection was 25 days after sowing and the second one was done one month later.
The chemical analysis of tested extracts is presented in Table (2). Wheat seeds were obtained from Agriculture Research Centre and they were sowing in the first week of December in both seasons of 2017/18 and 2018/19 at both sides of each lateral drip line. Wheat grains were 
hand drilled at the rate of $60 \mathrm{~kg} /$ feddan (feddan $=0.420$ hectares $=1.037$ acres). All plots received equal amount of compost at the rate of 8 ton /feddan that were added during soil preparation. The actual consumptive use $\left(\mathrm{ET}_{\mathrm{c}}\right)$ was calculated according to equation purposed by Allen (1998) as follows:

$\mathrm{ET}_{\mathrm{c}}=\mathrm{ET}_{\mathrm{o}} \times \mathrm{K}_{\mathrm{c}}$

Where, ETc = Crop evapotranspiration. $\mathrm{ET}_{0}=$ Reference evapotranspiration. Kc $=$ Crop coefficient (according to FAO paper No. 56).

Table (2): The chemical analysis of tested extracts.

\begin{tabular}{|l|l|l|}
\hline Property & Chicken manure extract & Sheep manure extract \\
\hline Organic matter \% & 52.65 & 35.17 \\
\hline Extract raction $(\mathrm{pH})$ & 7.12 & 8.39 \\
\hline Extract salinity $(\mathrm{EC} \mathrm{dS} / \mathrm{m})$ & 3.51 & 4.91 \\
\hline Total macronutrient $(\%)$ & \multicolumn{2}{|l|}{} \\
\hline $\mathrm{N}$ & 2.98 & 2.01 \\
\hline $\mathrm{P}$ & 2.75 & 1.26 \\
\hline $\mathrm{K}$ & 3.12 & 3.69 \\
\hline Total micronutrient $(\mathrm{mg} / \mathrm{kg})$ & \\
\hline $\mathrm{Fe}$ & 1355 & 4125 \\
\hline $\mathrm{Mn}$ & 185 & 143 \\
\hline $\mathrm{Zn}$ & 189 & 79 \\
\hline
\end{tabular}

The CROPWAT model was used to calculate crop evapotranspiration by Penman Monteith equation (Smith, 1991). The amounts of actually applied irrigation water requirement under each irrigation treatment were determined according to James (1988) using the following equation:

$$
\mathrm{I} \operatorname{Ra}=\frac{\mathrm{ETc}+\mathrm{Lf}}{\mathrm{Er}}
$$

Where, $\mathrm{IR}_{\mathrm{a}}=$ total actual irrigation water applied $\mathrm{mm}$ /irrigation. $\mathrm{ET}_{\mathrm{c}}=$ Crop evapotranspiration using Penman Monteith equation. $\mathrm{Lf}=$ leaching factor $10 \% . \mathrm{Er}=$ irrigation system efficiency.

Crop water productivity (CWP) was calculated according to Vites (1965) using the following equations:

$\mathrm{CWP}=$ grain yield $(\mathrm{kg} /$ feddan $) /$ Seasonal ET $\left(\mathrm{m}^{3} /\right.$ feddan $)$

After 75 days from planting, 10 wheat plants were randomly selected from each treatment to measure plant height and spike length. Moreover, at harvesting time, 10 wheat plants were chosen randomly from each plot to determine spike number $/ \mathrm{m}^{2}$ and weight of 1000 grain. The straw and grains yield of each plot were recorded then they converted to biological yield and total grain yield as $\mathrm{kg} /$ feddan. The obtained data were statistical analyzed using MSTAT-C program according to Gomez and Gomez (1984). Duncan multiple range tests at 
$5 \%$ level of probability was used to test the significant of differences between the treatments.

\section{Results and Discussion}

\subsection{Applied irrigation water}

The seasonal amounts of applied irrigation water for wheat crop were positively affected by drip irrigation treatments of 100, 80 and $60 \%$ of crop evapotranspiration (ETc). The seasonal amounts of applied irrigation water were 2641.5, 2113.2 and $1589.9 \mathrm{~m} 3 /$ feddan for 100,80 and $60 \% \mathrm{ET}_{\mathrm{c}}$, respectively in the first season (Table 3). They were 2334.7, 1867.8 and $1400.8 \mathrm{~m} 3 /$ feddan for the corresponding treatments in the second season (2018/19). There were almost no changes due to use different varieties or manure extract. It was noticed that the total amounts of applied irrigation water in the $1^{\text {st }}$ season were higher than that in the $2^{\text {nd }}$ one. This difference may be attributed to the differences in the meteorological data between both seasons. The data revealed that applied irrigation water vary from growth stage to another through both seasons. The applied irrigation water increased gradually in the initial stage then increased sharply to reach its peak in the mid growth stage then started to decrease in the late stage (Table 3). Oweis et al. (2000) found that evapotrans piration (ET) value increased as supplemental irrigation was increased for wheat crop, since ET ranged from 338 to $382 \mathrm{~mm}$ at $1 / 3$ of full supplemental irrigation and from 434 to $453 \mathrm{~mm}$ at full supplemental one. Also, Khalil et al. (2006) reported that water consumptive use (WCU) increased as the available soil moisture were increased in the root zone of the plants. While, subjecting wheat plants to soil water deficit caused a decrease in WCU.

Table (2): Amount of applied water ( $\mathrm{m}^{3} /$ feddan) for wheat crop at different growth stage under different irrigation regimes through both growing seasons.

\begin{tabular}{|l|c|c|c|c|c|c|c|c|c|}
\hline \multirow{2}{*}{ Growth stages } & \multicolumn{3}{|c|}{$2017 / 2018$} & \multicolumn{3}{c|}{$2018 / 2019$} & \multicolumn{3}{c|}{ Average of both seasons } \\
\cline { 2 - 11 } & $100 \%$ & $80 \%$ & $60 \%$ & $100 \%$ & $80 \%$ & $60 \%$ & $100 \%$ & $80 \%$ & $60 \%$ \\
\hline Initial stage & 115.34 & 92.27 & 69.2 & 100.35 & 80.28 & 60.21 & 107.84 & 86.27 & 64.71 \\
\hline Development stage & 223.09 & 178.47 & 133.85 & 215.96 & 172.77 & 129.58 & 219.53 & 175.62 & 131.72 \\
\hline Mid- season stage & 1611.27 & 1289.02 & 966.76 & 1391.7 & 1113.36 & 835.02 & 1501.49 & 1201.19 & 900.89 \\
\hline Late-season stage & 691.81 & 553.45 & 415.09 & 626.72 & 501.37 & 376.03 & 659.27 & 527.41 & 395.56 \\
\hline Total & 2641.51 & 2113.21 & 1584.91 & 2334.73 & 1867.78 & 1400.84 & 2488.12 & 1990.5 & 1492.87 \\
\hline
\end{tabular}

* The values are average of both varieties and manure extract.

El-Sayed (2007) stated that the daily water consumed varied with growth stages. It started small at the initial stage then it increased gradually to reach the peak values at flowering stage (in March) after that it declined. The highest value of daily consumptive use $(5.04 \mathrm{~mm})$ was obtained during mid stage under flooding 
irrigation at $13 \%$ soil moisture depletion (SMD). While the lowest value of daily consumptive use $(2.30 \mathrm{~mm})$ was obtained during initial stage under drip irrigation at $75 \%$ SMD.

\subsection{Some wheat growth traits}

\subsubsection{Plant height}

Wheat plant heights as affected by irrigation regime and manure extract application for two wheat varieties during the growing season of 2017/18 and 2018/19 are shown in Table (4). In general, wheat plant heights became shorter by decreasing the irrigation water for both varieties during both growing seasons. The opposite trend was true with manure extract besides the sheep manure extract was superior to that of chicken manure extract (Table 4). This may be attributed to increasing the nutrients availability and their uptake especially $\mathrm{K}$ and its role in stimulating cell division that stimulates early growth and its activation photosynthesis (Aşık et $a l ., 2009)$. On the average basis, the plant heights were $71.73,75.14$ and $78.28 \mathrm{~cm}$ for control, chicken and sheep manure extract, respectively in the $1^{\text {st }}$ season. They were $77.90,81.31$ and $84.44 \mathrm{~cm}$ for the corresponding treatments in the $2^{\text {nd }}$ season. Giza 171 wheat variety realized taller plants than that of Misr-1as well as the plants in the $2^{\text {nd }}$ season were taller than that in the $1^{\text {st }}$ season. Growing Giza171 or Misr-1 wheat variety that treated by sheep manure extract and irrigated at
$100 \% \mathrm{ET}_{\mathrm{c}}$ realized the tallest wheat plants for both seasons, while the shortest plants were obtained at $60 \% \mathrm{ET}_{\mathrm{c}}$ without addition of any manure extract (control treatment, CK). Gopinath et al. (2008) stated that morphological changes in growth can be considered as a morphological adaptation of the plant to water and environmental stresses to reduce transpiration and to induce a lower consumption of water. Shah et al. (2013) observed that the tallest plants were obtained by using $100 \%$ of ETo, while the $70 \%$ of ETo treatment resulted in the shortest plants in both seasons.

\subsubsection{Spike length}

Wheat spike length of both varieties as affected by irrigation regimes and manure extracts during 2017/18 and 2018/19 growing seasons are presented in Table (4). In general, spike length followed the same trend of plant height since it increased by increasing the irrigation water for both varieties during both growing seasons. Sidrak (2003) revealed that exposing wheat plants to water stress condition reflected a significant depression of spike length. ElSayed (2007) found that the highest spike length was recorded at $13 \%$ SMD under flooding irrigation. The spike length was boosted by adding manure extract compared to control treatment. This effect was more obvious with sheep manure extract and in the $2^{\text {nd }}$ season. On the average basis, the spike length was $10.79,10.82$ and $11.99 \mathrm{~cm}$ for control, 
chicken and sheep manure extract, respectively in the $1^{\text {st }}$ season. They were $11.99,12.47$ and $13.70 \mathrm{~cm}$ for the corresponding treatments in the $2^{\text {nd }}$ season. Growing Giza-171 or Misr-1 wheat variety that treated by sheep manure extract and irrigated at $100 \%$ ETc realized the tallest spike length for both seasons, while the shortest spike length were obtained at $60 \%$ ETc without addition of any manure extract (control treatment, CK).

Table (4): Effect of irrigation regime and manure extraction on some growth traits of two wheat varieties during the growing season of 2017/18 and 2018/19.

\begin{tabular}{|c|c|c|c|c|c|c|c|c|c|c|c|c|c|c|}
\hline \multirow{3}{*}{ Season } & \multirow{3}{*}{ Manure extract addition } & \multirow{3}{*}{$\begin{array}{l}\text { Irrigation } \\
\text { regime }\end{array}$} & \multicolumn{3}{|c|}{ Plant height $(\mathrm{cm})$} & \multicolumn{3}{|c|}{ Spike length $(\mathrm{cm})$} & \multicolumn{3}{|c|}{ Spike number/ $\mathrm{m}^{2}$} & \multicolumn{3}{|c|}{ Weight of 1000 grain $(\mathrm{g})$} \\
\hline & & & \multicolumn{2}{|c|}{ Variety } & \multirow{2}{*}{ Mean } & \multicolumn{2}{|c|}{ Variety } & \multirow{2}{*}{ Mean } & \multicolumn{2}{|c|}{ Variety } & \multirow{2}{*}{ Mean } & \multicolumn{2}{|c|}{ Variety } & \multirow{2}{*}{ Mean } \\
\hline & & & Giza 171 & Misr-1 & & Giza 171 & Misr-1 & & Giza 171 & Misr-1 & & \begin{tabular}{|l|} 
Giza 171 \\
\end{tabular} & Misr-1 & \\
\hline \multirow{12}{*}{ 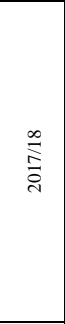 } & \multirow{4}{*}{ Without (Control, CK) } & $100 \%$ & $79.07 \mathrm{c}$ & $78.87 \mathrm{~d}$ & $79.27 \mathrm{~d}$ & $11.94 \mathrm{~b}$ & $11.71 \mathrm{c}$ & $12.18 \mathrm{~b}$ & $367 \mathrm{~d}$ & $351 \mathrm{~g}$ & $383 \mathrm{f}$ & $47.96 \mathrm{c}$ & $50.08 \mathrm{~d}$ & $45.85 \mathrm{f}$ \\
\hline & & $80 \%$ & $71.77 \mathrm{e}$ & $70.40 \mathrm{~g}$ & $73.13 \mathrm{f}$ & $10.62 \mathrm{e}$ & $10.37 \mathrm{~h}$ & $10.88 \mathrm{~g}$ & $384 \mathrm{f}$ & $319 \mathrm{~h}$ & $448 \mathrm{~g}$ & $31.81 \mathrm{~g}$ & $32.91 \mathrm{k}$ & $30.71 \mathrm{~m}$ \\
\hline & & $60 \%$ & $61.83 \mathrm{~h}$ & $60.87 \mathrm{k}$ & $62.80 \mathrm{j}$ & $9.38 \mathrm{~g}$ & $9.44 \mathrm{ij}$ & $9.31 \mathrm{j}$ & $300 \mathrm{~g}$ & $280 \mathrm{i}$ & $319 \mathrm{~h}$ & $27.98 \mathrm{i}$ & 28.49 no & $27.47 \mathrm{o}$ \\
\hline & & mean & $70.89 \mathrm{c}$ & $70.04 \mathrm{e}$ & $71.73 \mathrm{~d}$ & $10.65 \mathrm{~b}$ & $10.51 \mathrm{~d}$ & $10.79 \mathrm{c}$ & $350 \mathrm{c}$ & $316 \mathrm{e}$ & $383 \mathrm{~d}$ & $35.92 \mathrm{c}$ & $37.16 \mathrm{c}$ & $34.68 \mathrm{e}$ \\
\hline & \multirow{4}{*}{ Chicken manure extract $(\mathrm{CH})$} & $100 \%$ & $81.85 \mathrm{~b}$ & $79.73 \mathrm{~cd}$ & $83.97 \mathrm{~b}$ & $11.46 \mathrm{c}$ & $11.38 \mathrm{cde}$ & $11.54 \mathrm{~cd}$ & $436 \mathrm{~b}$ & $384 \mathrm{f}$ & $488 \mathrm{~b}$ & $51.19 \mathrm{~b}$ & $54.27 \mathrm{~b}$ & $48.11 \mathrm{e}$ \\
\hline & & $80 \%$ & $74.12 \mathrm{~d}$ & $72.00 \mathrm{f}$ & $76.23 \mathrm{e}$ & $11.15 \mathrm{~d}$ & $10.99 \mathrm{f} \mathrm{g}$ & $11.31 \mathrm{def}$ & $380 \mathrm{c}$ & $357 \mathrm{~g}$ & $403 \mathrm{~d} \mathrm{e}$ & $34.40 \mathrm{e}$ & $36.53 \mathrm{i}$ & $32.28 \mathrm{kl}$ \\
\hline & & $60 \%$ & $65.40 \mathrm{~g}$ & $65.57 \mathrm{i}$ & $65.23 \mathrm{i}$ & $9.60 \mathrm{~g}$ & $9.59 \mathrm{ij}$ & $9.60 \mathrm{ij}$ & $350 \mathrm{e}$ & $310 \mathrm{~h}$ & $391 \mathrm{ef}$ & $30.22 \mathrm{~h}$ & $31.70 \mathrm{~lm}$ & $28.75 n$ \\
\hline & & mean & $73.79 \mathrm{~b}$ & $72.43 \mathrm{~d}$ & $75.14 \mathrm{c}$ & $10.74 \mathrm{~b}$ & $10.65 \mathrm{~cd}$ & $10.82 \mathrm{c}$ & $388 \mathrm{~b}$ & $350 \mathrm{~d}$ & $427 \mathrm{~b}$ & $38.60 \mathrm{~b}$ & $40.83 \mathrm{~b}$ & $36.38 \mathrm{~d}$ \\
\hline & \multirow{4}{*}{ Sheep manure extract $(\mathrm{SH})$} & $100 \%$ & $84.62 \mathrm{a}$ & $83.10 \mathrm{~b}$ & $86.13 \mathrm{a}$ & $13.03 \mathrm{a}$ & $12.31 \mathrm{~b}$ & $13.75 \mathrm{a}$ & $492 \mathrm{a}$ & $450 \mathrm{c}$ & $535 \mathrm{a}$ & $54.37 \mathrm{a}$ & $57.10 \mathrm{a}$ & $51.65 \mathrm{c}$ \\
\hline & & $80 \%$ & $79.07 \mathrm{c}$ & $77.30 \mathrm{e}$ & $80.83 \mathrm{c}$ & $11.78 \mathrm{~b}$ & $11.16 \mathrm{efg}$ & $12.39 \mathrm{~b}$ & $425 \mathrm{~b}$ & $414 \mathrm{~d}$ & $436 \mathrm{c}$ & $39.51 \mathrm{~d}$ & $38.72 \mathrm{~h}$ & $40.29 \mathrm{~g}$ \\
\hline & & $60 \%$ & $67.93 \mathrm{f}$ & $68.00 \mathrm{~h}$ & $67.87 \mathrm{~h}$ & $10.12 \mathrm{f}$ & $10.43 \mathrm{~h}$ & $9.81 \mathrm{i}$ & $381 \mathrm{c}$ & $354 \mathrm{~g}$ & $409 \mathrm{~d}$ & $32.78 \mathrm{f}$ & $34.27 \mathrm{j}$ & $31.29 \mathrm{~lm}$ \\
\hline & & mean & $77.21 \mathrm{a}$ & $76.13 \mathrm{~b}$ & $78.28 \mathrm{a}$ & $11.64 \mathrm{a}$ & $11.30 \mathrm{~b}$ & $11.99 \mathrm{a}$ & $433 \mathrm{a}$ & $406 \mathrm{c}$ & $460 \mathrm{a}$ & $42.22 \mathrm{a}$ & $43.36 \mathrm{a}$ & $41.08 \mathrm{~b}$ \\
\hline \multirow{12}{*}{$\frac{\stackrel{\infty}{\infty}}{\stackrel{d}{\sigma}}$} & \multirow{4}{*}{ Without (Control, CK) } & $100 \%$ & $85.23 \mathrm{c}$ & $85.03 \mathrm{~d}$ & $85.43 \mathrm{~d}$ & $12.45 \mathrm{c}$ & $12.24 \mathrm{~h}$ & $12.66 \mathrm{fg}$ & $357 \mathrm{~d}$ & $338 \mathrm{gh}$ & $376 \mathrm{ef}$ & $49.87 \mathrm{c}$ & $51.99 \mathrm{~d}$ & $47.76 \mathrm{f}$ \\
\hline & & $80 \%$ & $77.93 \mathrm{e}$ & $76.57 \mathrm{~g}$ & $79.30 \mathrm{f}$ & $12.04 \mathrm{~d}$ & $11.59 \mathrm{i}$ & $12.48 \mathrm{~g}$ & $315 \mathrm{f}$ & $306 \mathrm{i}$ & $325 \mathrm{~h}$ & $33.72 \mathrm{~g}$ & $34.82 \mathrm{k}$ & $32.62 \mathrm{~m}$ \\
\hline & & $60 \%$ & $68.00 \mathrm{~h}$ & $67.03 \mathrm{k}$ & $68.97 \mathrm{j}$ & $10.81 \mathrm{~g}$ & 10.781 & $10.84 \mathrm{kl}$ & $285 \mathrm{~g}$ & $269 \mathrm{j}$ & $301 \mathrm{i}$ & $29.89 \mathrm{i}$ & 30.40 no & 29.38 o \\
\hline & & mean & $77.06 \mathrm{c}$ & $76.21 \mathrm{e}$ & $77.90 \mathrm{~d}$ & $11.77 \mathrm{c}$ & $11.54 \mathrm{e}$ & $11.99 \mathrm{~d}$ & $319 \mathrm{c}$ & $304 \mathrm{e}$ & $334 \mathrm{~d}$ & $37.83 \mathrm{c}$ & $39.07 \mathrm{c}$ & $36.59 \mathrm{e}$ \\
\hline & \multirow{4}{*}{ Chicken manure extract $(\mathrm{CH})$} & $100 \%$ & $88.02 \mathrm{~b}$ & $85.90 \mathrm{~cd}$ & $90.13 \mathrm{~b}$ & $13.32 \mathrm{~b}$ & $12.98 \mathrm{e}$ & $13.67 \mathrm{~d}$ & $419 \mathrm{~b}$ & $370 \mathrm{ef}$ & $469 \mathrm{~b}$ & $53.10 \mathrm{~b}$ & $56.18 \mathrm{~b}$ & $50.02 \mathrm{e}$ \\
\hline & & $80 \%$ & $80.28 \mathrm{~d}$ & $78.17 \mathrm{f}$ & $82.40 \mathrm{e}$ & $12.46 \mathrm{c}$ & $12.17 \mathrm{~h}$ & \begin{tabular}{|l|}
$12.74 \mathrm{f}$ \\
\end{tabular} & $367 \mathrm{~d}$ & $336 \mathrm{gh}$ & $399 \mathrm{~d}$ & $36.31 \mathrm{e}$ & $38.44 \mathrm{i}$ & $34.19 \mathrm{kl}$ \\
\hline & & $60 \%$ & $71.57 \mathrm{~g}$ & $71.73 \mathrm{i}$ & $71.40 \mathrm{i}$ & 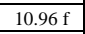 & $10.92 \mathrm{kl}$ & $10.99 \mathrm{k}$ & $330 \mathrm{e}$ & $294 \mathrm{i}$ & $367 \mathrm{f}$ & $32.13 \mathrm{~h}$ & $33.61 \mathrm{~lm}$ & $30.66 n$ \\
\hline & & mean & $79.96 \mathrm{~b}$ & $78.60 \mathrm{~d}$ & $81.31 \mathrm{c}$ & $12.25 \mathrm{~b}$ & $12.02 \mathrm{~d}$ & $12.47 \mathrm{c}$ & $372 \mathrm{~b}$ & $333 \mathrm{~d}$ & $412 \mathrm{~b}$ & $40.51 \mathrm{~b}$ & $42.74 \mathrm{~b}$ & $38.29 \mathrm{~d}$ \\
\hline & \multirow{4}{*}{ Sheep manure extract $(\mathrm{SH})$} & $100 \%$ & $90.78 \mathrm{a}$ & $89.27 \mathrm{~b}$ & $92.30 \mathrm{a}$ & $14.73 \mathrm{a}$ & $13.93 \mathrm{c}$ & $15.54 \mathrm{a}$ & $474 \mathrm{a}$ & $433 \mathrm{c}$ & $515 \mathrm{a}$ & $56.28 \mathrm{a}$ & $59.01 \mathrm{a}$ & $53.56 \mathrm{c}$ \\
\hline & & $80 \%$ & $85.23 \mathrm{c}$ & $83.47 \mathrm{e}$ & $87.00 \mathrm{c}$ & $13.34 \mathrm{~b}$ & $12.54 \mathrm{~g}$ & $14.14 \mathrm{~b}$ & $405 \mathrm{c}$ & $399 \mathrm{~d}$ & $411 \mathrm{~d}$ & $41.42 \mathrm{~d}$ & $40.63 \mathrm{~h}$ & $42.20 \mathrm{~g}$ \\
\hline & & $60 \%$ & $74.10 \mathrm{f}$ & $74.17 \mathrm{~h}$ & $74.03 \mathrm{~h}$ & $11.33 \mathrm{e}$ & $11.31 \mathrm{j}$ & $11.43 \mathrm{j}$ & $362 \mathrm{~d}$ & $341 \mathrm{~g}$ & $383 \mathrm{e}$ & $34.59 \mathrm{f}$ & $36.18 \mathrm{j}$ & $33.20 \mathrm{~lm}$ \\
\hline & & mean & $83.37 \mathrm{a}$ & $82.30 \mathrm{~b}$ & $84.44 \mathrm{a}$ & $13.13 \mathrm{a}$ & $12.59 \mathrm{~b}$ & $13.70 \mathrm{a}$ & $414 \mathrm{a}$ & $391 \mathrm{c}$ & $436 \mathrm{a}$ & $44.13 \mathrm{a}$ & $45.27 \mathrm{a}$ & $42.99 \mathrm{~b}$ \\
\hline
\end{tabular}

\subsubsection{Spike number}

Spike number $/ \mathrm{m}^{2}$ as affected by irrigation regime and manure extract application for two wheat varieties during the growing season of 2017/18 and 2018/19 are shown in Table (4). In general, spike number $/ \mathrm{m}^{2}$ followed the same trend of spike length since it increased by increasing the irrigation water for both varieties during both growing seasons. El-Sayed (2007) found that the highest spike number/ $\mathrm{m} 2$ was recorded at $13 \%$ SMD under drip and the lowest one was obtained under sprinkler irrigation at $75 \%$ SMD. The spike number $/ \mathrm{m}^{2}$ was greater with adding manure extract compared to control treatment. This impact was more pronounced with sheep manure extract and in the $2^{\text {nd }}$ season. On the average basis, the spike number $/ \mathrm{m}^{2}$ was 383,427 and 460 for control, chicken and sheep manure extract, respectively in the $1^{\text {st }}$ season. They were 334, 412 and 436 for the corresponding treatments in the $2^{\text {nd }}$ season. Growing Giza-171 or Misr-1 wheat variety that treated by sheep 
manure extract and irrigated at $100 \% \mathrm{ET}_{\mathrm{c}}$ realized the greater spike number $/ \mathrm{m}^{2}$ for both seasons, while the smallest spike number $/ \mathrm{m}^{2}$ were realized at $60 \% \mathrm{ET}_{\mathrm{c}}$ without addition of any manure extract (control treatment, $\mathrm{CK}$ ).

\subsubsection{Weight of 1000-grain}

The weight of 1000-grain (g) as affected by irrigation regime and manure extract application for two wheat varieties during the growing season of 2017/18 and 2018/19 are shown in Table (4). In general, the weight of 1000-grain increased significantly by increasing the irrigation water for both varieties during both growing seasons. El-Sayed (2007) found that the highest value of seed index (weight of 1000-grain) was recorded at $75 \%$ SMD under drip and the lowest one was obtained under flooding irrigation at $75 \%$ SMD. The weight of 1000-grain was greater with adding manure extract compared to control treatment. This impact was more pronounced with sheep manure extract and in the $2^{\text {nd }}$ season. On the average basis, the weight of 1000grain was 34.68, 36.38 and $41.08 \mathrm{~g}$ for control, chicken and sheep manure extract, respectively in the $1^{\text {st }}$ season. They were $36.59,38.29$ and $42.99 \mathrm{~g}$ for the corresponding treatments in the $2^{\text {nd }}$ season. Growing Giza-171 or Misr-1 wheat variety that treated by sheep manure extract and irrigated at $100 \%$ ETc realized the greater weight of 1000grain for both seasons, while the smallest weight of 1000-grain were realized at
$60 \%$ ETc without addition of any manure extract (control treatment, $\mathrm{CK}$ ).

\subsection{Wheat yield}

\subsubsection{Biological yield}

Data in Table (5) show the effect of irrigation regime and manure extract application for two wheat varieties during the growing season of 2017/18 and $2018 / 19$ on the biological yield. The biological yield increased significantly as the irrigation water increased for both varieties during both growing seasons. Hoover et al. (2019) found that wheat biological yield irrigated at 1.2 and 1.0 of accumulated pan evaporation (PEC) increased significantly by 4.2 and $4.4 \%$ in the $1^{\text {st }}$ season and by 11.7 and $5.8 \%$ in the $2^{\text {nd }}$ one compared to irrigation scheduling at 0.8 PEC, respectively. Also, the biological yield increased significantly with the application of manure extract and it was more pronounced with sheep manure extract as well as in the $2^{\text {nd }}$ season. On the average basis, the biological yield was 3523.07, 3656.70 and $3824.76 \mathrm{~kg} /$ feddan for control, chicken and sheep manure extract, respectively in the $1^{\text {st }}$ season. They were 3978.06, 4139.40 and 4363.64 $\mathrm{kg} /$ feddan for the corresponding treatments in the $2^{\text {nd }}$ season. Growing Giza-171 or Misr-1 wheat variety that treated by sheep manure extract and irrigated at $100 \% \mathrm{ET}_{\mathrm{c}}$ realized the greater biological yield for both seasons, while the smallest biological yield were 
realized at $60 \% \mathrm{ET}_{\mathrm{c}}$ without addition of any manure extract (control treatment, CK). Also, there was insignificant differences between both tested varieties in the biological yield.

\subsubsection{Grain yield}

Data presented in Table (5) indicate that the total grain yield was significantly affected by irrigation regimes and manure extract application for both verities during both growing seasons. Wheat grain yield increased significantly as the irrigation water increased and by manure extract application. On the average basis, the grain yield was $1127.74,1317.23$ and $1483.19 \mathrm{~kg} /$ feddan for control, chicken and sheep manure extract, respectively in the $1^{\text {st }}$ season. They were $1190.58,1384.29$ and 1565.59 $\mathrm{kg} /$ feddan for the corresponding treatments in the $2^{\text {nd }}$ season. Growing Giza-171 or Misr-1 wheat variety that treated by sheep manure extract and irrigated at $100 \%$ ETc realized the highest grain yield for both seasons, while the smallest grain yield were realized at $60 \%$ ETc without addition of any manure extract $(\mathrm{CK})$.

Table (5): Effect of irrigation regime and manure extraction on wheat yield and water productivity during the growing season of 2017/18 and 2018/19.

\begin{tabular}{|c|c|c|c|c|c|c|c|c|c|c|c|}
\hline \multirow{3}{*}{ Season } & \multirow{3}{*}{ Manure extract addition } & \multirow{3}{*}{ Irrigation regime } & \multicolumn{3}{|c|}{ Biological yield $(\mathrm{kg} / \mathrm{fed})$} & \multicolumn{3}{|c|}{ Grain yield $(\mathrm{kg} / \mathrm{fed})$} & \multicolumn{3}{|c|}{ Water productivity $\left(\mathrm{kg} / \mathrm{m}^{3}\right)$} \\
\hline & & & \multicolumn{2}{|c|}{ Variety } & \multirow{2}{*}{ Mean } & \multicolumn{2}{|c|}{ Variety } & \multirow{2}{*}{ Mean } & \multicolumn{2}{|c|}{ Variety } & \multirow{2}{*}{ Mean } \\
\hline & & & Giza 171 & Misr-1 & & Giza 171 & Misr-1 & & Giza 171 & Misr-1 & \\
\hline \multirow{12}{*}{$\underset{\stackrel{\infty}{i}}{\stackrel{\infty}{i}}$} & \multirow{4}{*}{ Without (Control, CK) } & $100 \%$ & $3831.77 \mathrm{c}$ & $3814.42 \mathrm{de}$ & $3849.12 \mathrm{~d}$ & $1421.46 \mathrm{c}$ & $1412.05 \mathrm{e}$ & $1430.88 \mathrm{e}$ & $0.54 \mathrm{e}$ & $0.53 \mathrm{hi}$ & $0.54 \mathrm{~h}$ \\
\hline & & $80 \%$ & $3514.37 \mathrm{e}$ & $3453.14 \mathrm{~g}$ & $3575.60 \mathrm{f}$ & $1043.42 \mathrm{f}$ & $991.51 \mathrm{~h}$ & $1095.33 \mathrm{~g}$ & $0.49 \mathrm{~g}$ & $0.47 \mathrm{j}$ & $0.52 \mathrm{i}$ \\
\hline & & $60 \%$ & $3096.63 \mathrm{~h}$ & $3048.76 \mathrm{k}$ & $3144.49 \mathrm{j}$ & $816.11 \mathrm{i}$ & $775.20 \mathrm{k}$ & $857.03 \mathrm{j}$ & $0.52 \mathrm{f}$ & $0.49 \mathrm{j}$ & $0.54 \mathrm{~h}$ \\
\hline & & mean & $3480.92 \mathrm{c}$ & $3438.77 \mathrm{f}$ & $3523.07 \mathrm{e}$ & $1093.67 \mathrm{c}$ & $1059.59 \mathrm{e}$ & $1127.74 \mathrm{~d}$ & $0.52 \mathrm{c}$ & $0.50 \mathrm{e}$ & $0.53 \mathrm{~d}$ \\
\hline & \multirow{4}{*}{ Chicken manure extract $(\mathrm{CH})$} & $100 \%$ & $3945.42 \mathrm{~b}$ & $3922.88 \mathrm{c}$ & $3967.96 \mathrm{c}$ & $1615.38 \mathrm{~b}$ & $1521.08 \mathrm{~d}$ & $1709.67 \mathrm{c}$ & $0.61 \mathrm{c}$ & $0.58 \mathrm{~g}$ & $0.65 \mathrm{~d}$ \\
\hline & & $80 \%$ & $3669.89 \mathrm{~d}$ & $3563.22 \mathrm{f}$ & $3776.56 \mathrm{e}$ & $1198.28 \mathrm{e}$ & $1124.04 \mathrm{~g}$ & $1272.52 \mathrm{f}$ & $0.57 \mathrm{~d}$ & $0.53 \mathrm{hi}$ & $0.60 \mathrm{ef}$ \\
\hline & & $60 \%$ & $3240.49 \mathrm{~g}$ & $3255.40 \mathrm{i}$ & $3225.57 \mathrm{i}$ & $917.32 \mathrm{~h}$ & $865.13 \mathrm{j}$ & $969.51 \mathrm{~h}$ & $0.58 \mathrm{~d}$ & $0.55 \mathrm{~h}$ & $0.61 \mathrm{e}$ \\
\hline & & mean & $3618.60 \mathrm{~b}$ & $3580.50 \mathrm{~d}$ & $3656.70 \mathrm{c}$ & $1243.66 \mathrm{~b}$ & $1170.09 \mathrm{c}$ & $1317.23 \mathrm{~b}$ & $0.59 \mathrm{~b}$ & $0.55 \mathrm{c}$ & $0.62 \mathrm{~b}$ \\
\hline & \multirow{4}{*}{ Sheep manure extract (SH) } & $100 \%$ & $4155.54 \mathrm{a}$ & $4112.68 \mathrm{~b}$ & $4198.40 \mathrm{a}$ & $1855.80 \mathrm{a}$ & $1773.59 \mathrm{~b}$ & $1938.02 \mathrm{a}$ & $0.70 \mathrm{a}$ & $0.67 \mathrm{c}$ & $0.73 \mathrm{a}$ \\
\hline & & $80 \%$ & $3860.83 \mathrm{c}$ & $3788.40 \mathrm{e}$ & $3933.26 \mathrm{c}$ & $1363.15 \mathrm{~d}$ & $1233.66 \mathrm{f}$ & $1492.63 \mathrm{~d}$ & $0.65 \mathrm{~b}$ & $0.59 \mathrm{fg}$ & $0.71 \mathrm{~b}$ \\
\hline & & $60 \%$ & $3325.25 \mathrm{f}$ & $3307.88 \mathrm{~h}$ & $3342.61 \mathrm{~h}$ & $969.38 \mathrm{~g}$ & $919.85 \mathrm{i}$ & $1018.91 \mathrm{~h}$ & $0.61 \mathrm{c}$ & $0.58 \mathrm{~g}$ & $0.64 \mathrm{~d}$ \\
\hline & & mean & $3780.54 \mathrm{a}$ & $3736.32 \mathrm{~b}$ & $3824.76 \mathrm{a}$ & $1396.11 \mathrm{a}$ & $1309.03 \mathrm{~b}$ & $1483.19 \mathrm{a}$ & $0.65 \mathrm{a}$ & $0.61 \mathrm{~b}$ & $0.69 \mathrm{a}$ \\
\hline \multirow{12}{*}{$\frac{\stackrel{\infty}{\infty}}{\stackrel{\infty}{\tilde{N}}}$} & \multirow{4}{*}{ Without (Control, CK) } & $100 \%$ & $4284.15 \mathrm{~d}$ & $4274.11 \mathrm{ef}$ & $4294.20 \mathrm{e}$ & $1496.58 \mathrm{c}$ & \begin{tabular}{|l|}
$1425.19 \mathrm{f}$ \\
\end{tabular} & $15.67 .96 \mathrm{e}$ & $0.64 \mathrm{f}$ & $0.61 \mathrm{j}$ & $0.67 \mathrm{~h}$ \\
\hline & & $80 \%$ & $3977.43 \mathrm{f}$ & $3883.52 \mathrm{j}$ & $4071.33 \mathrm{~g}$ & $1121.43 \mathrm{f}$ & $1101.42 \mathrm{j}$ & $1141.44 \mathrm{i}$ & $0.60 \mathrm{~g}$ & $0.59 \mathrm{k}$ & $0.61 \mathrm{j}$ \\
\hline & & $60 \%$ & $3521.08 \mathrm{i}$ & $3473.52 \mathrm{~m}$ & 3568.641 & $844.74 \mathrm{i}$ & $827.13 \mathrm{n}$ & $862.35 \mathrm{~m}$ & $0.60 \mathrm{~g}$ & $0.59 \mathrm{k}$ & $0.61 \mathrm{ij}$ \\
\hline & & mean & $3927.55 \mathrm{c}$ & $3877.05 \mathrm{e}$ & $3978.06 \mathrm{~d}$ & $1154.25 \mathrm{c}$ & $1117.91 \mathrm{f}$ & $1190.58 \mathrm{e}$ & $0.61 \mathrm{c}$ & $0.60 \mathrm{f}$ & $0.63 \mathrm{e}$ \\
\hline & \multirow{4}{*}{ Chicken manure extract $(\mathrm{CH})$} & $100 \%$ & $4380.34 \mathrm{~b}$ & $4348.21 \mathrm{~d}$ & $4412.46 \mathrm{c}$ & $1700.79 \mathrm{~b}$ & $1616.96 \mathrm{~d}$ & $1785.31 \mathrm{~b}$ & $0.73 \mathrm{c}$ & $0.69 \mathrm{~g}$ & $0.77 \mathrm{c}$ \\
\hline & & $80 \%$ & $4131.75 \mathrm{e}$ & $3996.68 \mathrm{~h}$ & $4266.82 \mathrm{ef}$ & $1258.31 \mathrm{e}$ & $1168.99 \mathrm{i}$ & $1347.63 \mathrm{~g}$ & $0.68 \mathrm{e}$ & $0.63 \mathrm{ij}$ & $0.72 \mathrm{f}$ \\
\hline & & $60 \%$ & $3656.85 \mathrm{~h}$ & 3574.781 & $3738.91 \mathrm{k}$ & $954.31 \mathrm{~h}$ & $888.69 \mathrm{~m}$ & $1019.92 \mathrm{k}$ & $0.68 \mathrm{e}$ & $0.63 \mathrm{i}$ & $0.73 \mathrm{ef}$ \\
\hline & & mean & $4056.31 \mathrm{~b}$ & $3973.22 \mathrm{~d}$ & $4139.40 \mathrm{c}$ & $1304.47 \mathrm{~b}$ & $1224.65 \mathrm{~d}$ & $1384.29 \mathrm{~b}$ & $0.69 \mathrm{~b}$ & $0.65 \mathrm{~d}$ & $0.74 \mathrm{~b}$ \\
\hline & \multirow{4}{*}{ Sheep manure extract (SH) } & $100 \%$ & $4637.42 \mathrm{a}$ & $4563.11 \mathrm{~b}$ & $4711.72 \mathrm{a}$ & $1925.59 \mathrm{a}$ & $1749.44 \mathrm{c}$ & $2101.74 \mathrm{a}$ & $0.83 \mathrm{a}$ & $0.75 \mathrm{~cd}$ & $0.90 \mathrm{a}$ \\
\hline & & $80 \%$ & $4332.95 \mathrm{c}$ & $4223.00 \mathrm{f}$ & $4442.91 \mathrm{c}$ & 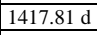 & 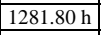 & $1553.82 \mathrm{e}$ & $0.76 \mathrm{~b}$ & $0.69 \mathrm{gh}$ & $0.83 \mathrm{~b}$ \\
\hline & & $60 \%$ & $3862.39 \mathrm{~g}$ & $3788.47 \mathrm{k}$ & $3936.31 \mathrm{i}$ & $990.91 \mathrm{~g}$ & \begin{tabular}{|l|}
940.6311 \\
\end{tabular} & $1041.20 \mathrm{k}$ & $0.71 \mathrm{~d}$ & \begin{tabular}{|l|}
$0.67 \mathrm{~h}$ \\
\end{tabular} & $0.74 \mathrm{de}$ \\
\hline & & mean & $4277.59 \mathrm{a}$ & $4191.53 \mathrm{~b}$ & $4363.64 \mathrm{a}$ & $1444.77 \mathrm{a}$ & $1323.96 \mathrm{c}$ & $1565.59 \mathrm{a}$ & $0.77 \mathrm{a}$ & $0.70 \mathrm{c}$ & $0.82 \mathrm{a}$ \\
\hline
\end{tabular}

Also, there was insignificant differences between both tested varieties in the grain yield. Yaduvanshi and Sharma (2008) found that application of farmyard manure with chemical amendment increase the wheat yield and $\mathrm{N}, \mathrm{P}, \mathrm{K}$, uptake in grain yield. Shah et al. (2013) found that the highest values of 
biological yields, Grain yields, straw yields, ear lengths, grains numbers/ row, rows numbers/ ear, grains number/ear and 1000-grains weight were obtained through irrigation scheduling at 1.2 values of accumulated pan evaporation. Hoover et al. (2019) reported that there is a positive effect as a result of applying farmyard manure at rate of $10 \mathrm{ton} / \mathrm{ha}$ on the wheat grain yield that increased by $62.74 \%$ than the control.

\subsubsection{Water productivity}

Water productivity is defined as the attainable grain yield per unit of irrigation water applied. The data in table (5) show the effects of irrigation regime and manure extract application on water productivity for both wheat varieties during both growing seasons. Water productivity increased significantly as the irrigation water increased and by manure extract application. These results are in disagree of those obtained by El-Saei et al. (2006) who concluded that the field crop water productivity (FCWP) increased as the soil moisture stress increased. Kobierski et al. (2017) mentioned that increasing irrigation levels did not increase the water productivity. On the average basis, water productivity was $0.53,0.62$ and $0.69 \mathrm{~kg} /$ $\mathrm{m}^{3}$ for control, chicken and sheep manure extract, respectively in the $1^{\text {st }}$ season. They were $0.63,0.74$ and $0.83 \mathrm{~kg} / \mathrm{m}^{3}$ for the corresponding treatments in the $2^{\text {nd }}$ season. Improving soil fertility improves water productivity by increasing photosynthetic capacity of the leaf through improved enzyme function and enhanced carbon dioxide assimilation (Shah et al., 2013). Growing Giza-171 or Misr-1 wheat variety that treated by sheep manure extract and irrigated at $100 \% \mathrm{ET}_{\mathrm{c}}$ realized the highest water productivity for both seasons, while the smallest water productivity were realized at $60 \% \mathrm{ET}_{\mathrm{c}}$ without addition of any manure extract (control treatment, CK). Also, there was insignificant differences between both tested varieties in water productivity. Hoover et al. (2019) found that subsurface drip irrigation increased wheat crop water productivity (WP) by $24.95 \%$ and irrigation water productivity by $19.59 \%$ compared to flood irrigation. It might be concluded that application of manure extract with proper irrigation practice increase the agriculture potential of sandy calcareous soil that suffer in general from less nutrients content and water shortage with high soil reaction. Adding sheep manure extract with full irrigation water requirement $\left(100 \mathrm{ET}_{\mathrm{c}}\right)$ realized the best agricultural practices for wheat growth and crop water productivity.

\section{References}

Abo-Elela, E. G. Y. (2002), The dynamic changes in chemical and mineralogical characteristics of calcids soils as affected by natural soil amendments, Ph.D. Thesis, Department of Soils and Water, Faculty of Agriculture, Ain Shams University, Egypt. 
Allen, G. R., Pereira, L. S., Raes, D. and Smith, M. (1998), Crop evapotranspiration, guidelines for competing crop water requirements, paper 56, Irrigation and drainages, FAO, Rome, Italy.

Deksissa, T., Short, I. and Allen, J. (2008), Effect of Soil Amendment with Compost on Growth and Water Use efficiency of Amaranth, In: Proceedings of The Annual Conference, International Water Resources, Challenges for the $21^{\text {st }}$ Century and Water Resources Education, Durham, North Carolina, USA.

Delate, K. and Camberdella, C. A. (2004), "Agro-ecosystem performance during transition to certified organic grain production", Agronomy Journal, Vol. 96, pp.1288-1298.

Gewaily, E. E. (2019), "Influence of arbuscular mycorrhizal fungi (AMF) inoculation on the performance of Sakha 107 rice cultivar under different irrigation intervals ", Environment, Biodiversity and Soil Security, Vol. 3, pp. 119-129.

James, L. G. (1988), Principles of farm irrigation systems design, Washington State University, USA, pp. 543.

Manqiang, L., Feng, H., Xiaoyun, C., Qianru, H., Jiaguo, J., Bin, Z. and Huixin, L. (2009), "Organic amendments with reduced chemical fertilizer promote soil microbial development and nutrient availability in a subtropical paddy field: The influence of quantity, type and application time of organic amendments ", Applied Soil Ecology, Vol. 42, pp. 166-175.

Oad, F., Buriro, C. U. A. and Agha, S. K. (2004), "Effect of organic and inorganic fertilizer application on maize fodder production", Asian Journal of Plant Sciences, Vol. 3, pp. 375-377.

Reddy, S. S., Shivaraj, B., Reddy, V. C. and Ananda, M. G. (2005),"Direct effect of fertilizer and esidual effect of organic manure on yield and nutrient uptake of maize (Zea may L.) in groundnut-maize cropping system", Crop Research, Vol. 29, pp. 390-395.

Refai, E. F. S., Mostafa, H. H. A., Hefzy, M. and Zahran, M. M. A. A. (2019), "Enhance of water use efficiency, productivity and quality of lettuce (Lactuca sativa L.) on newly reclaimed soils", Middle East Journal of Applied Sciences, Vol. 9 No. 2, pp. 464-473.

Sanchez-Monedero, M., Mondini, C., Nobili, M., Leita, L. and Roig, A. (2004), "Land application of biosolids. Soil response to different stabilization degree of the treated organic matter", Waste Management, Vol. 24, pp. 325-532.

Smith, N. (1991), CROPWAT model for ETo calculation using penman monteith method, FAO, Rome, Italy. 
Oweis, T., Zhang, H. and Pala, M. (2000), "Water use efficiency of rainfed and irrigated bread wheat in a Miditerranean environment", Agronomy Journal, Vol. 92, pp. 231-238.

Khalil, F. A. F., Tammam, A. M., Amin, I. A. and Mohamed, K. A. (2006), "Scheduling irrigation for some wheat cultivars under upper Egypt conditions", Mansoura University Journal of Agricultural Sciences, Vol. 31 No. 1, pp. 561-572.

El-Sayed, M. M. (2007), Water Requirements of Wheat and Sunflower under Different Irrigation Systems at Assiut, M.Sc. Thesis, Faculty of Agriculty, Assiut University, Egypt.

Sidrak, N. N. (2003), Scheduling irrigation of wheat using the evaporation pan method under different times and rates of nitrogen fertilizer, M.Sc. Thesis, Faculty of Agriculture, Zagazig University, Egypt.

El-Saei, M. A, E. M. El-Hadidi and A. Talaat (2006), "Water Saving by applying potassium fertilization and water stress with wheat crop", Mansoura University Journal of Agricultural Sciences, Vol. 31 No. 7, pp. 4825-4835.

Asik, B. B., Turanm, A., Celik, H. and Katkat, A.V. (2009), "Effects of humic substances on plant growth and mineral nutrients uptake of wheat (Triticum durum cv. Salihi) under condions of salinity", Asian Journal of Crop Science, Vol. 1 No. 2, pp. 87-95.

Meena, K. B., Alam, M. S., Singh, H., Bhat, M. A., Singh, A. K., Mishra, A. K. and Thomas, T. (2018), "Influence of farmyard manure and fertilizers on soil properties and yield and nutrient uptake of wheat", International Journal of Chemical Studies, Vol. 6 No. 3, pp. 386-390.

Yaduvanshi, N. P. S. and Sharma, D. R. (2008), "Tillage and residual organic manures/chemical amendment effects on soil organic matter and yield of wheat under sodic water irrigation", Soil \& Tillage Research, Vol. 98, pp.11-16.

Vites, F. G. (1965), Increasing water use efficiency by soil management, America Society Agronomy, Madison, Wisconsin, USA, pp. 259 274.

Gomez, K. A. and Gomez, A. A., 1984, Statistical Procedures for Agricultural Research, $2^{\text {nd }}$ Edition, John Wiley and Sons, New York, USA.

Gopinath, K. A., Saha, S., Mina, B. L., Pande, H., Kundu, S. and Gupta, H. S. (2008), "Influence of organic amendments on growth, yield and quality of wheat and on soil properties during transition to organic production", Nutrient Cycling in Agroecosystems, Vol. 82, pp. 51-60.

Shah, J. A., Depar, N. Memon, M. Y., 
Aslam, M. and Sial, N. A. (2013), Kobierski, M., Bartkowiak, A., "Integration of organic and mineral nutrient sources enhances wheat production", Pakistan Journal of Agriculture, Agricultural Engineering and Veterinary Sciences, Vol. 29, pp. 106-113.

Lemanowicz, J. and Mariusz, P. (2017), "Impact of poultry manure fertilization on chemical and biochemical properties of soils", Plant, Soil and Environment, Vol. 63 No. 12, pp. 558-563.

Hoover, N., Law, J., Long, L. A. M., Kanwar, R. S. and Soupir, M. L.(2019), "Long-term impact of poultry manure on crop yield, soil and water quality, and crop revenue", Journal of Environmental Management, Vol. 252, pp. 109582. 